an excess of barium hydroxide is $b f^{-} \sim$, added and the conductance increases. A basic, difficultly soluble hydroxide of cadmium of the composition $\mathrm{CdSO}_{4} \cdot \mathrm{Cd}(\mathrm{OH})_{2}$ was reported by $\mathrm{Kühn} .^{1}$ T'his was obtained in triclinic needles by boiling a solution of cadmium sulfate with one-third of an equivalent of potassium hydroxide. No mention has been made of a compound of the composition $\mathrm{CdSO}_{4 \cdot 3} \mathrm{Cd}(\mathrm{OH})_{2}$. Although the above titration would indicate the existence of this compound, a thorough investigation of equilibria in the system $\mathrm{CdO}-\mathrm{CdSO}_{4}-\mathrm{H}_{2} \mathrm{O}$ would be necessary before definite proof would be obtained. The author wishes to express his thanks to Mr. Harry Beckerman for some of the first titrations of magnesium sulfate and copper sulfate.

\title{
Summary.
}

I. The use of a barium hydroxide solution has been suggested for the determination of metals in sulfate solutions by the conductance method.

2. A suitable apparatus has been constructed for carrying out such titrations in an atmosphere free from carbon dioxide.

3. The method as outlined in this paper has proved to be sound for the determination of magnesium in magnesium sulfate; also, for the determination of magnesium in a solution containing magnesium sulfate. calcium sulfate and sulfuric acid; and finally, an accurate and rapid method has been suggested and tested for the determination of magnesium in dolomite.

4. Copper sulfate, nickel sulfate, and cobalt sulfate can also be titrated by this method.

5. Titration of cadmium sulfate indicates the formation of an oxysulfate of the composition $\mathrm{CdSO}_{4} \cdot 3 \mathrm{Cd}(\mathrm{OH})_{2}$.

Philadelpeis, PA.

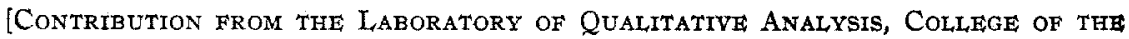
CITY OF NEW YORK.]

\section{THE INTERFERENCE OF THIOCYANATES, FERROCYANIDES AND FERRICYANIDES IN THE DETECTION OF IODIDES WITH PALLADIUM.}

By Louis J. Curtman and Ben R. Harris. Received November 27, 1916.

In a recent paper of the authors ${ }^{2}$ attention was called to the observations made by $\operatorname{Kern}^{3}$ that thiocyanates, ferrocyanides and ferricyanides interfere with the precipitation of iodides as palladium iodide. Since Kern does not, however, supply detailed data to show the nature and extent of the several interferences, it was thought worth while to carry out the experiments recorded below for the purpose of furnishing such information.

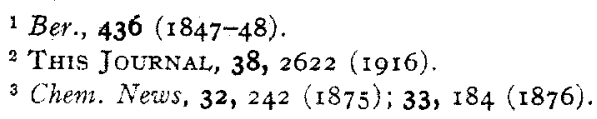


Procedure. - A definite vc'1 1 me of a standard potassium iodide solution was measured into a test tube. To this were added, in the order named, a definite amount of a standard solution of the potassium salt of the interfering acid, one drop of 10\% hydrochloric acid, 2 cc. of palladium chloride solution ${ }^{1}$ and sufficient water to give a volume of $5 \mathrm{cc}$. The mixture was shaken and allowed to stand three minutes. Observations were made by comparing with a blank. The results obtained are tabulated below.

\begin{tabular}{|c|c|c|c|c|c|}
\hline \multirow{2}{*}{$\begin{array}{l}\mathrm{Mg} . \\
\mathrm{SCN} .\end{array}$} & \multicolumn{5}{|c|}{ Mg. of I. } \\
\hline & 0.0 & 1 & 5 & 10. & 50. \\
\hline I & $\begin{array}{l}\text { Dull golden } \\
\text { yellow soln. }\end{array}$ & Slight ppt. ${ }^{2}$ & $\begin{array}{l}\text { Heavy black } \\
\text { ppt. }\end{array}$ & $\ldots \ldots \ldots$ & $\ldots \ldots$ \\
\hline 5 & $\begin{array}{l}\text { Reddish floc- } \\
\text { culent ppt. }\end{array}$ & $\begin{array}{l}\text { Chocolate- } \\
\text { colored ppt. }\end{array}$ & $\begin{array}{l}\text { Heavy black } \\
\text { ppt. }\end{array}$ & $\ldots \ldots \ldots$ & \\
\hline IO & $\begin{array}{l}\text { Reddish floc- } \\
\text { culent ppt. }\end{array}$ & $\begin{array}{l}\text { Reddish floc- } \\
\text { culent ppt. }\end{array}$ & $\begin{array}{l}\text { Dark reddish } \\
\text { brown ppt. }\end{array}$ & $\begin{array}{l}\text { Heavy black } \\
\text { ppt. }\end{array}$ & \\
\hline 25 & $\begin{array}{l}\text { Clear orange- } \\
\text { red soln. }\end{array}$ & $\begin{array}{l}\text { Slight reddish } \\
\text { ppt. }\end{array}$ & $\begin{array}{l}\text { Slight reddish } \\
\text { ppt. }\end{array}$ & Clear red soln. & Deep red soln. \\
\hline
\end{tabular}

From the blanks obtained with 5 and Io $\mathrm{mg}$. of SCN, it may be seen that the interference caused by those amounts of thiocyanate is due to the precipitation of reddish flocculent palladious thiocyanate; ${ }^{2}$ while $25 \mathrm{mg}$. of SCN causes the formation of soluble potassium palladiothiocyanate. $^{3}$ In both cases, the palladium added is not available for the precipitation of iodides.

In the presence of $25 \mathrm{mg}$. $\mathrm{SCN}$, the addition of three times the amount of palladium originally used, still gave a negative result with I mg. I. With $5 \mathrm{mg}$. I the same excess of palladium produced a chocolate-brown precipitate.

In the determination of the interference of ferrocyanides and ferricyanides the same procedure was followed except that in addition to the first observation made 3 minutes after the dilution of the mixture to $5 \mathrm{cc}$., a second observation was made seven minutes later and finally a third observation was made after boiling, for $\mathrm{r}^{-}-3$ o seconds, the mixture which had been standing ro minutes. The results are shown in Tables II and III.

${ }^{1}$ The palladium solution used was prepared by dissolving Merck's palladium foil in a mixture consisting of concentrated hydrochloric and nitric acids in the proportion of ro to $x$, respectively, evaporating twice to dryness on the steam bath with concentrated hydrochloric acid and finally taking up the residue with water containing hydrochloric acid. Filtration was sometimes necessary to render the solution clear. The solution contained approximately $\mathrm{r}$ cc. of concentrated hydrochloric acid per Ioo $\mathrm{cc}$. and $5 \mathrm{mg}$. of palladium per cc.

2 The appearance of the mother liquor with the precipitate in suspension was dull red.

${ }^{3}$ Roscoe and Schorlemmer's, "Treatise on Chemistry," 2, I317 (1907). 
TABLE II.-INThRFERENCE OF FerRocyanides.

\begin{tabular}{|c|c|c|c|c|c|c|c|}
\hline \multirow{2}{*}{$\begin{array}{l}\text { Min- } \\
\text { utes. }\end{array}$} & \multirow{2}{*}{$\mathrm{Fe}(\mathrm{Mg}) \boldsymbol{r}^{\mathrm{MV}}$} & \multicolumn{6}{|c|}{ Mg. of I. } \\
\hline & & 0.0. & 1. & 5. & 10. & 20. & 35. \\
\hline 3 & I & $\begin{array}{l}\text { Light } \\
\text { brown } \\
\text { soln. }\end{array}$ & $\begin{array}{l}\text { Opaque } \\
\text { brownish } \\
\text { black } \\
\text { soln. }\end{array}$ & $\begin{array}{l}\text { Opaque } \\
\text { brownish } \\
\text { black } \\
\text { soln. }\end{array}$ & $\begin{array}{l}\text { Consider- } \\
\text { able } \\
\text { black } \\
\text { ppt. }\end{array}$ & $\ldots \ldots \ldots$ & $\ldots$. \\
\hline & 5 & $\begin{array}{l}\text { Cleat } \\
\text { brown } \\
\text { soln. }\end{array}$ & $\begin{array}{l}\text { Deep } \\
\text { reddish } \\
\text { brown } \\
\text { soln. }\end{array}$ & $\begin{array}{l}\text { Opaque } \\
\text { brownish } \\
\text { black } \\
\text { soln. }\end{array}$ & $\begin{array}{l}\text { Consider- } \\
\text { able } \\
\text { black } \\
\text { ppt. }\end{array}$ & $\ldots \ldots$ & \\
\hline & Io & $\begin{array}{l}\text { Light } \\
\text { brown } \\
\text { soln. }\end{array}$ & $\ldots \ldots$ & $\begin{array}{l}\text { Slight } \\
\text { brown } \\
\text { ppt. }\end{array}$ & $\begin{array}{l}\text { Opaque } \\
\text { brownish } \\
\text { black } \\
\text { soln. }\end{array}$ & $\begin{array}{l}\text { Opaque } \\
\text { brownish } \\
\text { black } \\
\text { soln. }\end{array}$ & $\begin{array}{l}\text { Slight } \\
\text { black } \\
\text { ppt. }\end{array}$ \\
\hline & 25 & $\begin{array}{l}\text { Clear } \\
\text { brown } \\
\text { soln. }\end{array}$ & & $\begin{array}{l}\text { Opaque } \\
\text { brownish } \\
\text { black } \\
\text { soln. }\end{array}$ & $\begin{array}{l}\text { Opaque } \\
\text { brownish } \\
\text { black } \\
\text { soln. }\end{array}$ & $\begin{array}{l}\text { Slight } \\
\text { brownish } \\
\text { black } \\
\text { ppt. }\end{array}$ & $\begin{array}{l}\text { Slight } \\
\text { black } \\
\text { ppt. }\end{array}$ \\
\hline
\end{tabular}

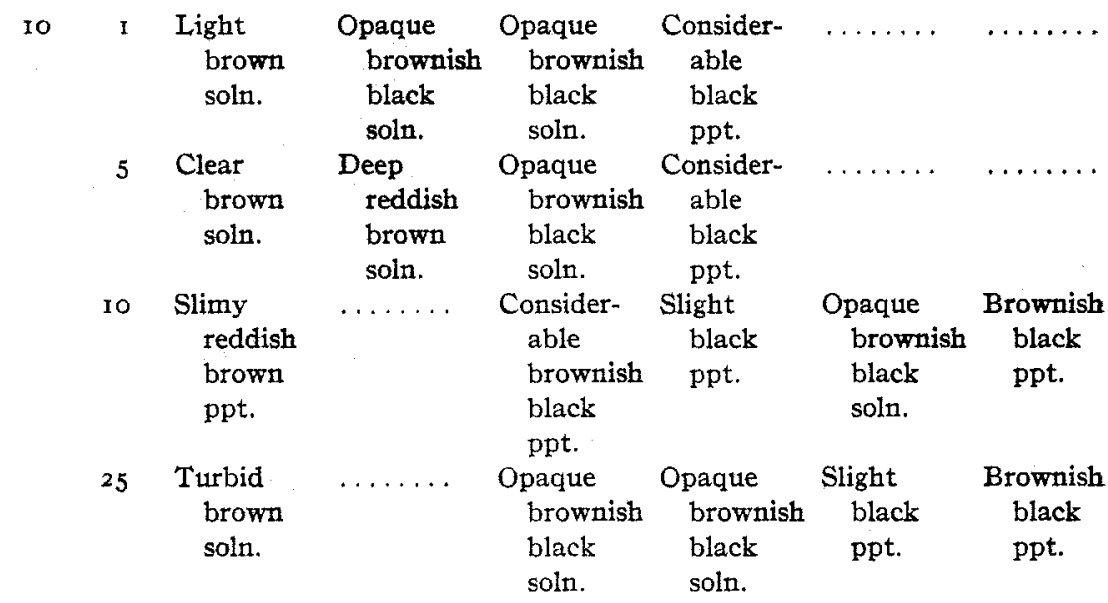

\begin{tabular}{|c|c|c|c|c|c|c|c|}
\hline $\begin{array}{l}\text { Boil- } \\
\text { ing }\end{array}$ & 1 & $\begin{array}{l}\text { Light } \\
\text { brown } \\
\text { soln. }\end{array}$ & $\begin{array}{r}\text { Black } \\
\text { ppt. }\end{array}$ & $\begin{array}{r}\text { Black } \\
\text { ppt. }\end{array}$ & & $\ldots \ldots$ & $\ldots$ \\
\hline & 5 & $\begin{array}{l}\text { Light } \\
\text { green } \\
\text { ppt. }\end{array}$ & $\begin{array}{c}\text { Brownish } \\
\text { black } \\
\text { ppt. }\end{array}$ & $\begin{array}{c}\text { Brownish } \\
\text { black } \\
\text { ppt. }\end{array}$ & & & \\
\hline & 10 & $\begin{array}{l}\text { Consider- } \\
\text { able } \\
\text { brown } \\
\text { ppt. } \\
\text { changing } \\
\text { to green }\end{array}$ & $\ldots \ldots$ & $\begin{array}{l}\text { Consider- } \\
\text { able } \\
\text { brownish } \\
\text { black ppt. } \\
\text { changing } \\
\text { to green }\end{array}$ & $\begin{array}{l}\text { Consider- } \\
\text { able } \\
\text { black } \\
\text { ppt. } \\
\text { changing } \\
\text { to green }\end{array}$ & $\begin{array}{l}\text { Black } \\
\text { ppt. } \\
\text { changing } \\
\text { to green- } \\
\text { ish blue }\end{array}$ & $\begin{array}{l}\text { Black } \\
\text { ppt. } \\
\text { changing } \\
\text { to green. } \\
\text { ish blue }\end{array}$ \\
\hline & 25 & $\begin{array}{l}\text { Greenish } \\
\text { blue ppt. }\end{array}$ & $\ldots \ldots$ & $\begin{array}{l}\text { Greenish } \\
\text { blue ppt. }\end{array}$ & $\begin{array}{l}\text { Greenish } \\
\text { blue ppt. }\end{array}$ & $\begin{array}{l}\text { Greenish } \\
\text { blue ppt. }\end{array}$ & Blue ppt. \\
\hline
\end{tabular}


TABLE III.-INTERFERENCE OF FERRICYANIDES.

\begin{tabular}{|c|c|c|c|c|c|c|c|}
\hline \multirow{2}{*}{\multicolumn{2}{|c|}{$\begin{array}{l}\text { Min- Mg. } \\
\text { utes. Fe(CN); }\end{array}$}} & \multicolumn{6}{|c|}{ Mg. of I. } \\
\hline & & $\overparen{0.0}$ & 1. & 5. & 10. & 15. & 20. \\
\hline \multirow[t]{4}{*}{$3-10$} & I & $\begin{array}{l}\text { Clear } \\
\text { reddish } \\
\text { brown } \\
\text { soln. }\end{array}$ & $\begin{array}{l}\text { Opaque } \\
\text { brownish } \\
\text { black } \\
\text { soln. }\end{array}$ & $\begin{array}{l}\text { Opaque } \\
\text { brownish } \\
\text { black } \\
\text { soln. }\end{array}$ & $\begin{array}{l}\text { Slight } \\
\text { black } \\
\text { ppt. }\end{array}$ & $\begin{array}{l}\text { Consider- } \\
\text { able } \\
\text { black } \\
\text { ppt. }\end{array}$ & \\
\hline & 5 & $\begin{array}{l}\text { Deep } \\
\text { red } \\
\text { soln. }\end{array}$ & $\begin{array}{l}\text { Deep } \\
\text { red } \\
\text { soln. }\end{array}$ & $\begin{array}{l}\text { Opaque } \\
\text { brownish } \\
\text { black } \\
\text { soln. }\end{array}$ & $\ldots \ldots$ & $\begin{array}{c}\text { Black } \\
\text { ppt. }\end{array}$ & $\ldots$ \\
\hline & IO & $\begin{array}{l}\text { Deep } \\
\text { red } \\
\text { soln. }\end{array}$ & $\begin{array}{l}\text { Deep } \\
\text { red } \\
\text { soln. }\end{array}$ & $\begin{array}{l}\text { Opaque } \\
\text { brownish } \\
\text { black } \\
\text { soln. }\end{array}$ & $\begin{array}{l}\text { Opaque } \\
\text { brownish } \\
\text { black } \\
\text { soln. }\end{array}$ & $\begin{array}{l}\text { Opaque } \\
\text { brownish } \\
\text { black } \\
\text { soln. }\end{array}$ & $\begin{array}{r}\text { Black } \\
\text { ppt. }\end{array}$ \\
\hline & 25 & $\begin{array}{c}\text { Reddish } \\
\text { brown } \\
\text { soln. }\end{array}$ & $\begin{array}{c}\text { Reddish } \\
\text { brown } \\
\text { soln. }\end{array}$ & $\ldots \ldots$ & $\begin{array}{l}\text { Opaque } \\
\text { brownish } \\
\text { black } \\
\text { soln. }\end{array}$ & $\begin{array}{r}\text { Black } \\
\text { ppt. }\end{array}$ & \\
\hline \multirow[t]{4}{*}{ Boiling } & $\mathbf{I}$ & $\begin{array}{l}\text { Clear } \\
\text { reddish } \\
\text { brown } \\
\text { soln. }\end{array}$ & $\begin{array}{r}\text { Black } \\
\text { ppt. }\end{array}$ & $\begin{array}{r}\text { Black } \\
\text { ppt. }\end{array}$ & $\begin{array}{r}\text { Black } \\
\text { ppt. }\end{array}$ & $\ldots \ldots$ & \\
\hline & 5 & $\begin{array}{l}\text { Deep } \\
\text { red } \\
\text { soln. }\end{array}$ & $\begin{array}{r}\text { Green } \\
\text { ppt. }\end{array}$ & $\begin{array}{r}\text { Black } \\
\text { ppt. }\end{array}$ & $\ldots \ldots$ & ........ & \\
\hline & Io & $\begin{array}{c}\text { Reddish } \\
\text { brown } \\
\text { ppt. }\end{array}$ & $\begin{array}{c}\text { Greenish } \\
\text { brown } \\
\text { ppt. }\end{array}$ & $\begin{array}{l}\text { Black } \\
\text { ppt. } \\
\text { changing } \\
\text { to green }\end{array}$ & $\begin{array}{l}\text { Black } \\
\text { ppt. } \\
\text { changing } \\
\text { to green }\end{array}$ & $\begin{array}{l}\text { Black } \\
\text { ppt. } \\
\text { changing } \\
\text { to green }\end{array}$ & \\
\hline & 25 & $\begin{array}{l}\text { Dark } \\
\text { brown } \\
\text { soln. }\end{array}$ & $\begin{array}{l}\text { Dark } \\
\quad \text { greenish } \\
\text { brown } \\
\text { soln. }\end{array}$ & $\ldots \ldots$ & $\begin{array}{r}\text { Black } \\
\text { ppt. }\end{array}$ & $\ldots \ldots \ldots$ & \\
\hline
\end{tabular}

The liquid which the authors have chosen to call $\varepsilon^{-}$"opaque brownish black solution" was of an unusual nature. It did not transmit light, hence it was impossible, merely by looking at the solution, to detect the presence of a precipitate. It was observed, however, that when a test tube containing a precipitate suspended in the opaque solution was shaken, black particles could be seen adhering to or sliding down the sides of the test tube. Since in the detection of iodides with palladium, the formation of a precipitate is the deciding factor, it is of vital importance to adopt a criterion whereby the presence of a precipitate is judged. Shaking the test tube and observing as noted above was the standard adopted for this work.

I mg. of iodine, as potassium iodide, precipitated under conditions which obtained in the experiments recorded above, except that no inter- 
fering acid was introduced, gave a distinctly visible, black precipitate in a transparent, light brown mother liquor.

An inspection of Tables II and III shows that by boiling the reaction mixture, the interference may in most cases be overcome. There are, however, many exceptions to this generalization.

\section{Summary.}

(I) Attention has been called to the interference of thiocyanates, ferrocyanides and ferrizyanides in the detection of iodides with palladium.

(2) Data have been furnished to show the nature and extent of the several interferences.

(3) It has been found that an excess of palladium favors the detection of iodides in the presence of thiocyanates.

(4) The interference occasioned by ferrocyanides and ferricyanides may in most instances be overcome by boiling the reaction mixture.

NEW YORK, N. Y.

NOTES.

Determination of Carbon Dioxide in Carbonates by Diminished Pressure.-Realizing the difficulty experienced by students in obtaining concordant results when determining the percentage of $\mathrm{CO}_{2}$ in carbonates by the absorption method, it seems worth while to mention a slight modification which has been adopted in this laboratory together with some of the results obtained.

The apparatus is arranged in the usual manner for the production and absorption of the gas but instead of the ordinary water suction pump an eight-liter aspirating bottle is used for the testing and finally for drawing air through. The aspirator is provided with a glass stopcock, which is opened wide before adding the acid to the reaction flask, thus bringing the system under slightly diminished pressure and it is left open during the entire operation, the flow of gas being regulated by means of a stopcock in the dropping funnel. The flow of gas ceases automatically when the aspirator is empty of water, which commends itself favorably to institutions having short laboratory periods.

The following results were obtained by four men in their first semester work in quantitative analysis: Correct percentage of $\mathrm{CO}_{2}, 43.94,44.96$, $45.67,46.40$. Percentage as determined, $43.95,44.95,45.64,46.36$. Eight liters of water were used in the aspirator in the above experiments. The calcium chloride used in these experiments was prepared by evaporating to dryness a solution of calcium chloride containing a few grams of ammonium chloride and then volatilizing the excess of ammonium chloride.

JOHN B. ZINN. 